\title{
Hvordan sikre god informasjon til etterlatte ved selvmord blant pasienter i psykisk helsevern
}

\author{
Ved Henning Herrestad og Kim Larsen
}

\begin{abstract}
I de nasjonale retningslinjene for forebygging av selvmord i psykisk helsevern anbefaler Helsedirektoratet (Shdir, 2008) at alle enheter i psykisk helsevern etablerer en prosedyre for oppfølging av etterlatte etter selvmord. I denne artikkelen vil vi gi mer utfyllende informasjon om hva et møte mellom etterlatte og behandlere kan inneholde. Hvem av de etterlatte bør omfattes av oppfølgingen?
\end{abstract}

\section{Prosedyren for oppfølging av etterlatte ved selvmord}

Kari Wille Rekdal (2009) forteller hvordan hun og hennes familie opplevde møtet med sykehuset som en ekstra belastning i sorgen etter mannens selvmord. De nasjonale retningslinjene for forebygging av selvmord i psykisk helsevern (Shdir, 2008) inneholder et eget punkt om ivaretakelse av pårørende og etterlatte. Her nevnes det at psykisk helsevern har fått mye kritikk for ikke å ha tilstrekkelig kontakt med etterlatte eller for ikke å ha gitt et godt nok tilbud om sorgst $\varnothing$ tte. Retningslinjene anbefaler derfor at:

"Det bør finnes prosedyrer for ivaretakelse av etterlatte etter selumord. Parørende og etterlatte bør få korrekt og rask informasjon, tilbud om samtale og bistand til videre oppfølging etter behov, samt informasjon om sine rettigheter, jf. kapittel 8 om rettslig grunnlag for helsehjelpen." (s. 27)

De rettigheter som det refereres til i nevnte kapittel 8 er følgende:

- Pårørende og etterlatte kan anmode tilsynsmyndighetene om en vurdering av mulige pliktbrudd etter pasientrettighetsloven § 7-4 og helsepersonellloven $\S 55$. Helsetilsynet skal gi den som har framsatt en slik anmodning, underretning om resultatet av behandlingen.

- Nærmeste pårørende har innsynsrett i journal etter en persons d $\varnothing \mathrm{d}$ når vilkårene i helsepersonelloven $\S 24$ er oppfylt.

- Pårørende og etterlatte kan søke erstatning i henhold til Norsk pasientskadeerstatning (NPE) i forbindelse med behandlingssvikt. (Jf. pasientskadeloven).

Retningslinjene angir også et eksempel på en slik prosedyre (s. 45-46). Prosedy- rens mål er å sikre at etterlatte ved selvmord blant pasienter i psykisk helsevern får tilbud om oppfølging fra sykehuset og blir ivaretatt. Prosedyren krever varsling av de etterlatte og beskriver hvordan dette bør skje. Deretter skal de etterlatte tilbys et møte med personalet og ansvarlig behandler for å medvirke til at et naturlig sorgarbeide kommer i gang, og for å redusere posttraumatiske reaksjoner.

Prosedyren angir følgende sjekkliste for hva man bør huske på i et møte mellom etterlatte og ansvarlig behandler:

- Det gis informasjon om hendelsen.

- Det settes av god tid til å svare på spørsmål.

- De etterlatte får tilbud om samtale med behandler eller annet helsepersonell som har vært i kontakt med pasienten.

- Det sikres at videre oppfølging blir gitt.

- De etterlatte orienteres om brukerorganisasjonen Landsforeningen for etterlatte ved selvmord (LEVE) og får brosjyre om LEVE samt navn på kontaktperson i lokalforening/fylkeslag.

- Det gis tilbud om å komme til avdelingen, bl.a. for å kunne se avdødes rom.

- Etterlatte gis anledning til å se avdøde.

- Pårørende opplyses om mulighet for innsyn i journal, mulighet til å s $\varnothing \mathrm{ke}$ NPE om erstatning og anledning til å anmode om tilsynssak hos helsetilsynet i fylket.

Prosedyren har også et avsnitt om obduksjon, og om hvordan oppfølgingen av de etterlatte avsluttes. Det anf $\varnothing$ res at oppfølgingsarbeid som gjøres overfor etterlatte, skal dokumenteres i tråd med kravene i journalforskriften.

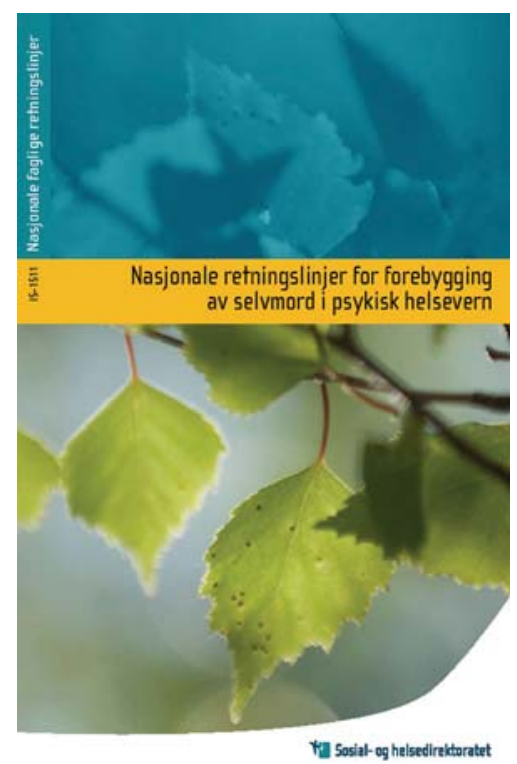

Hvem av de etterlatte bør få den foreskrevne oppfølgingen?

I retningslinjene brukes uttrykkene pårørende, etterlatte og nærmeste pårørende. Dette åpner for at man ut $\varnothing v e r$ et skjønn når man vurderer hvem som skal gis oppfølging. I forhold til innsynsrett i journal er det en avgrensning til nærmeste pårørende. Hvem som er nærmeste pårørende, er klart definert i pasientrettighetsloven. Nærmeste pårørende er den person som pasienten velger til denne funksjonen. For barn er nærmeste pårørende den eller de som har foreldreansvaret. Dersom en pasient har tatt sitt eget liv uten at det er journalført hvem pasienten har utpekt som nærmeste pårørende, gir § 1-3 bokstav b følgende avklaring:

"Dersom pasienten er ute av stand til a oppgi pårørende, skal nærmeste pårørende være den som $i$ størst utstrekning har varig og løpende kontakt med pasienten, likevel slik at det tas utgangspunkt i følgende rekkefølge: ektefelle, registrert partner, personer som lever i ekteskapslignende eller partnerskapslignende samboerskap med pasienten, 
myndige barn, foreldre eller andre med foreldreansvaret, myndige søsken, besteforeldre, andre familiemedlemmer som står pasienten nær, verge eller hjelpeverge."

Hovedregelen er at kun én person er nærmeste pårørende, men det kan være mer enn én dersom det for eksempel er flere barn som står i samme posisjon til avdøde. Rekkefølgen kan også snus dersom en annen enn den som formelt er nærmeste pårørende, har vært den som i størst utstrekning har hatt varig og løpende kontakt med pasienten. Det kan for eksempel hende at voksne barn har hatt nærmere kontakt med avd $\varnothing \mathrm{de}$ enn avdødes ektefelle (Befring et al., 2002). I noen situasjoner oppstår det konflikt om hvem som er pasientens nærmeste pårørende. Det er da opp til behandleren å ta denne avgjørelsen. Vi vil foreslå at den som skal invitere pårørende og andre etterlatte til et møte, først og fremst kontakter nærmeste pårørende, og at man spør nærmeste pårørende om det er andre som vedkommende mener bør gis oppfølging fra sykehuset. Spesielt bør man være oppmerksom på mindreårige barn av avdøde.

\section{Mer om informasjonen som gis til de pårørende og de etterlatte}

Et selvmord fører som regel til at de etterlatte sitter igjen med mange spørsmål. Den foreslåtte rutinen foreskriver derfor også at helsepersonell er tilgjengelig for telefonisk kontakt med de etterlatte rett etter at de farr $\mathrm{d} \varnothing \mathrm{d}$ sbudskapet. Det er også viktig at et møte med de etterlatte, der det er tid til å svare på spørsmål, blir arrangert få dager etter selvmordet. Samtidig er de etterlatte ofte i en sjokktilstand og får ikke med seg all den informasjonen som gis muntlig. Derfor bør man gi de etterlatte heftet "Til deg som har mistet noen i selvmord" (2009), hvor de kan få praktiske råd og informasjon om vanlige sorgreaksjoner.

Retningslinjene sier at formålet med møtet med de etterlatte er å ivareta dem, å medvirke til at et naturlig sorgarbeide kommer i gang, og å redusere posttraumatiske reaksjoner. I denne artikkelen har vi avgrenset oss til å si noe om hvor-

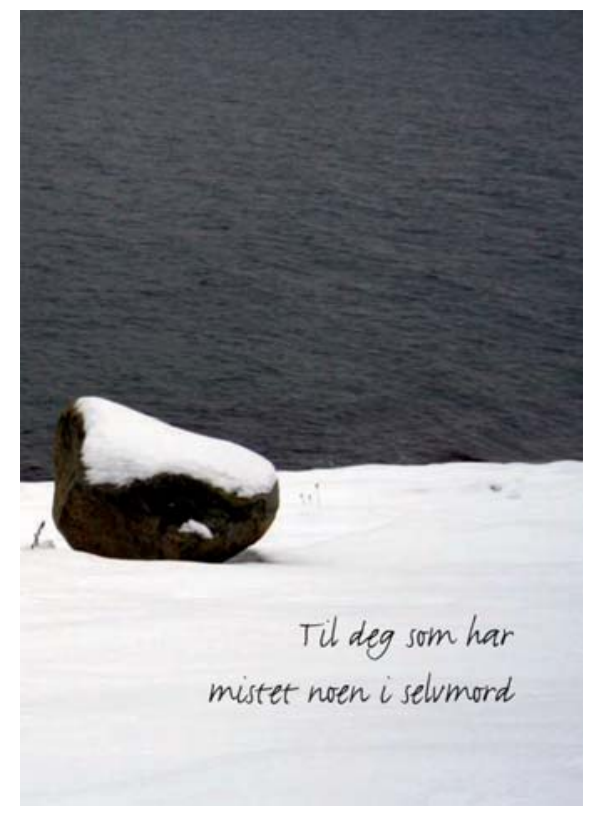

dan etterlatte kan ivaretas gjennom å gi informasjon om hva som har skjedd, om avd $\varnothing$ de og de etterlattes rettigheter.

Pårørende til innlagte pasienter regner med at sykehuset vil hindre at pasienten tar sitt eget liv. Dette er ikke en urimelig forventning. Sykehuset har jo tilgang til langt flere beskyttelsestiltak enn man har utenfor. For en utenforstående kan det virke uforståelig at selvmord kan skje selv når alle er oppmerksomme på faren og kan gripe inn for å forhindre det. Men for ansatte i sykehus er det trolig åpenbart at behandlingstiltak (medikamentell behandling, psykoterapi) og beskyttelsestiltak (hindre tilgang til selvmordsmetoder, kroppsvisitasjon, observasjon etc.) vil kunne forhindre mange selvmord, men ikke alle. Det er viktig å formidle til de pårørende at det ikke finnes noen måte å avgjøre med sikkerhet om en pasient kommer til å ta sitt eget liv eller ikke. Man kan sette i verk maksimal beskyttelse om man er bekymret for dette, men bare i en kort periode. Slike tiltak kan vanskeliggjøre behandlingen av pasientens grunnlidelse. Det at det har skjedd et selvmord, indikerer derfor ikke i seg selv at det har foregått en svikt i behandling eller oppfølging av pasienten. Sykehuset kan til en viss grad forebygge at de pårørende blir skuffede og sinte når et selvmord skjer gjennom å ha en dialog med de pårørende om risikoen for at dette kan skje. Om sykehuset ikke har hatt noen slik dialog med de pårørende, må man regne med at de etterlatte opplever selvmordet som en svikt og et svik mot den tillit de har hatt til sykehuset.

For de etterlatte kan i enkelte tilfeller det å klandre sykehuset for det som har skjedd, både avlaste dem selv for skyldfølelse og avdøde for ansvar. Det er viktig at personalet klarer å møte de etterlattes sinne uten dermed nødvendigvis å innrømme skyld (med mindre det åpenbart er gjort feil) eller å gå inn i en forsvarspreget argumentasjon. Rekdal (2009) skriver:

"At etterlatte fortvilet prøver å finne noen a legge skylden på $i$ en slik situasjon, er vel ikke mer enn naturlig, men det kan jo også meget vel være at det er blitt begått feil. Fagfolk må ikke avvise slike reaksjoner med at alle etterlatte onsker å finne en syndebukk."

De etterlatte kan ha behov for å laste sykehuset for dødsfallet. Det er viktig å være oppmerksom på dette når man informerer de etterlatte om deres rettigheter. Samtidig bør dette gjøres på en slik måte at de etterlatte ikke uten grunn slutter at det antagelig har skjedd en feil de bør avdekke og klage på. Man kan for eksempel si:

NN har tatt sitt eget liv mens NN var pasient ved [nawn på avdeling]. Vi har fors $ø k t$ a forebygge at dette skulle skje, men vi har ikke lyktes. Det beklager vi sterkt. Vi gjør nå en gjennomgang av våre rutiner for å finne ut om det har skjedd en svikt, eller om rutinene bør endres. Vi vil informere deg/ dere om resultatet av denne giennomgangen.

Om ikke de etterlatte alt er ute etter å få all tilgjengelig informasjon om avd $\varnothing$ de, foreslår vi at man i det første møtet ganske kortfattet opplyser de etterlatte om deres mulighet for innsyn i journal, mulighet til å s $\varnothing$ ke NPE om erstatning og anledning til å anmode om tilsynssak hos helsetilsynet i fylket. Man kan invitere dem til å ta kontakt for et nytt møte dersom de bestemmer seg for at de vil benytte retten til journalinnsyn. 


\section{Spesielt om innsyn i pasientens journal}

I pasientrettighetsloven $\S 5-1$ står det at nærmeste pårørende har rett til innsyn i journal etter en pasients $\mathrm{d} \varnothing \mathrm{d}$, om ikke særlige grunner taler mot dette. Denne innsynsretten er begrunnet $i$ at nærmeste pårørende antas å kunne ivareta avdødes og de etterlattes interesser. Det kan være en interesse i å finne ut om dødsfallet hadde sammenheng med en svikt i helsetjenestene, Påvisning av en svikt kan utløse forsikringssummer eller erstatninger for de etterlatte, og det kan føre til at behandlingsrutiner blir endret.

I helsepersonelloven $\$ 24$ gjentas det at nærmeste pårørende har rett til journalinnsyn, og det tilføyes at i vurderingen av om opplysninger skal gis, skal det tas hensyn til avd $\varnothing$ des antatte vilje, opplysningenes art og de pårørende og samfunnets interesser. Befring et al. (2002) skriver at dersom opplysningene r $\varnothing$ per sider ved den avdøde som blir oppfattet som svært negative eller sjokkerende, kan dette være et argument for at avdødes antatte vilje er at taushet beholdes. Utlevering av journal fordrer derfor at sykehuset går igjennom journalen og vurderer om det er deler av journalen som skal maskeres eller holdes tilbake.

Hvis de etterlatte gjør krav på innsyn i pasientens journal, bør personalet informere om

hvem som kan få innsyn i journalen (nærmeste pårørende),

hvordan (ved gjennomgang med behandler eller ved tilsending av utskrift/ kopi),

og hva journalen omfatter av dokumenter (behandleres journalinnf $\varnothing \mathbf{r}$ inger, epikriser, innkomstnotater, sykepleiejournal, medisinjournal, journal fra pårørendesamarbeid, notater fra annet helsepersonell som f.eks. sosionomer).

Dersom det foreligger særlige grunner til å la være å gi innsyn i hele eller deler av avd $\varnothing$ des journal, skal dette meddeles skriftlig. Det skal gis en begrunnelse for avslaget, og det skal opplyses om muligheten til å klage til helsetilsynet i fylket.
Det bør da samtidig gjøres helt klart at man anerkjenner de etterlattes interesse i å få så fullstendig informasjon som mulig. Man bør si tydelig at man ikke har til hensikt å skjule informasjon som kan avdekke svikt under dekke av å ivareta avd $\varnothing$ des antatte vilje.

Man bør advare om at det kan være emosjonelt utfordrende å lese pasientens journal. Man kan selv tilby å være tilgjengelig for å gjennomgå journalen med de etterlatte, svare på eventuelle uklarheter og forklare faguttrykk og lignende. Det er verd å nevne at journalskriving er en egen sjanger og kan misforstås av lesere som ikke kjenner den institusjonelle konteksten journalene er skrevet $i$.

Hvis de etterlatte er ute etter å avdekke mest mulig av hva som har skjedd, bør de informeres om at det er flere andre informasjonskilder enn sykehusets journal. Nærmeste pårørende kan også kreve innsyn i journal hos avd $\varnothing$ des fastlege, hos andre sykehusavdelinger avd $\varnothing$ de har vært behandlet ved, og fra NAV.

\section{Om adgangen til å klage}

Dersom det i kontakten med de etterlatte framgår at de $\varnothing$ nsker å fremme en klage over svikt i helsetjenesten avd $\varnothing \mathrm{de}$ mottok, bør sykehuspersonalet være behjelpelig med informasjon om hvordan man fremmer en klage. Informer om at rett adressat for en klage er helsetilsynet i fylket.

De etterlatte bør få vite hvor de kan få st $\varnothing$ tte i prosessen med å avdekke om det har skjedd en svikt og $\mathrm{i}$ å formulere en eventuell klage. Helsetilsynet i fylket har plikt til å gi råd og veiledning i forbindelse med klagen. De kan henvende seg til pasient- og brukerombudet i sitt hjemfylke og eventuelt til Norsk pasientforening. Både Norsk pasientforening og ombudet kan gi dem informasjon om rettigheter og rutiner, og bistå med å formulere eller videreformidle spørsmål eller klage til rett instans. Bistand fra Norsk Pasientforening og ombudet er gratis. De etterlatte kan også søke st $\varnothing t t e$ hos pasientorganisasjoner som Landsforeningen for pårørende innen psykiatri (LPP). De kan også vurdere om de vil betale for advokathjelp. De bør på forhånd forhøre seg om hva det vil koste. Advokaten de eventuelt kontakter, har plikt til å opplyse om muligheten for å søke fri rettshjelp og vilkårene for dette. Etterlatte kan også kontakte kommunehelsetjenesten eller sosialkontoret i kommunen for å få hjelp.

Idet en behandler blir klar over at de etterlatte $\varnothing$ nsker å fremme en klage over svikt i behandlingen, vil behandleren komme i en vanskelig dobbeltrolle. På den ene siden skal han/hun ivareta de etterlatte, på den andre siden er han/hun en de etterlatte kanskje mistenker for å ha sviktet pasienten. Behandleren bør derfor straks søke st $\varnothing$ tte hos sin nærmeste overordnende, og klinikkledelsen bør vurdere om en annen behandler skal fortsette kontakten med de etterlatte, eller om behandleren skal ha noen med seg i møter med de etterlatte. Dette gjelder også i de tilfeller der behandleren selv er sterkt følelsesmessig ber $\varnothing$ rt av selvmordet. Det bør da vurderes om noen med større avstand også skal være til stede i møtet med de pårørende (Nesje \& Lander, 2003).

\section{Om adgangen til å søke om pasientskadeerstatning}

De etterlatte bør få vite at dersom det blir påvist at avdøde var offer for en svikt i helsetjenesten, kan de søke om erstatning fra NPE. Man kan søke om pasientskadeerstatning senest tre år etter at man har forstått at det er behandlingen eller svikt i behandlingen som har ført til skaden. NPE er et statlig forvaltningsorgan underlagt Helse- og omsorgsdepartementet. NPEs nettsider gir informasjon om at for å ha krav på erstatning, må det foreligge et $\varnothing$ konomisk tap på minst fem tusen kroner. NPE informerer om at etterlatte har fătt medhold i s $\varnothing \mathrm{knad}$ om erstatning der svikt i form av manglende tilsyn/overvåkning eller mangelfull sikring har ledet til selvmord. Til begrepet behandlingssvikt regnes også svikt ved unders $\varnothing$ kelse, diagnostisering og oppf $\varnothing 1$ ging. Saker med problemstilling selumord eller selvmordsforsøk er avslått der det er konkludert med at pasientene har blitt 
riktig vurdert, fulgt opp eller behandlet, og at selvmord/selvmordsfors $\varnothing \mathrm{k}$ ikke kunne vært forutsett eller forhindret. Det kan være lett i ettertid å konkludere med at siden pasienten er $\mathrm{d} \varnothing \mathrm{d}$, må vurderingen ha vært feil. Vurderingen kan ha vært adekvat ut fra forutsetningene på det tidspunkt den ble gjort, selv om pasienten senere tok sitt liv.

\section{Konklusjon}

Når en pasient har tatt sitt eget liv, er det en viktig oppgave for sykehuset å ivareta de etterlatte. Det gjør man best ved å møte dem personlig og gi dem god og saklig informasjon. Samtidig som de etterlatte bør få m $\varnothing$ te personale som kjente avdøde, kan dette personalet selv trenge st $\varnothing t t e$ enten fordi de selv er ber $\varnothing$ rt av selvmordet, eller fordi de etterlatte laster dem for selvmordet. Kontakten med de etterlatte kan derfor framstå som en balansegang mellom å være deres st $\varnothing$ tte og deres motpart.

\section{Takk}

Forfatterne ønsker å rette en takk til de etterlatte og de sykehusansatte som har bidratt med informasjonen som var utgangspunkt for denne artikkelen, samt til fagfellene som har bidratt med mange gode forslag til forbedringer.

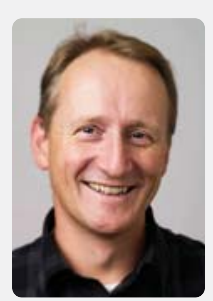

Henning Herrestad er ansatt i Sorgtjenesten i Fransiskushjelpen og er dessuten seniorrådgiver ved Nasjonalt senter for selvmordsforskning og -forebygging, $\mathrm{UiO}$.

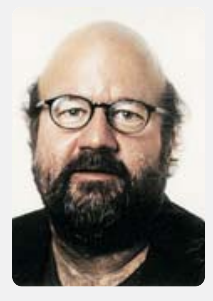

Kim Larsen er psykologspesialist ved Sykehuset Østfold og RVTS/ $\varnothing$. Han er spesialist i klinisk samfunnspsykologi og arbeids- og organisasjonspsykologi. Faglige spesialinteresser er: sosialpsykologi, Freudbiografi og psykoanalysens historie, psykiatrihistorie og suicidologi.

\section{Referanser}

Befring, A.K.C., Grytten, N.J., \& Ohnstad, B. (2002). Jus for leger. Kristiansand: Høyskoleforlaget.

Til deg som har mistet noen i selvmord. Et ressurshefte med viktig informasjon til etterlatte ved selvmord. Prosjektgruppe: Regionale ressursmiljøer og vold, traumatisk stress og selvmordsforebygging og Landsforeningen for etterlatte ved selvmord. Bestilles fra www.rvts.no eller lastes ned fra: http:// www.med.uio.no/ipsy/ssff/andre__ressurser/etterlatte/ brosjyretiletterlattefeb2009.pdf

Nesje, I., \& Lander, H. (2003). Selvmord i psykia-

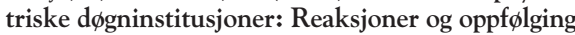
av etterlatte i familien og personalet. Prosjektoppgave Videreutdanning i selvmordsforebyggende arbeid, PDF tilgjengelig i duo.uio.no.

\section{Nasjonale konferanse om selv- mordsforebygging}

\section{Oslo, 4.-5. april 2011 Hold av dagene!}

\section{Mer info kommer.}

Rekdal, K.W. (2009). Ivaretakelse av pårørende og etterlatte ved selvmord: Kan de nye nasjonale retningslinjene ha betydning? Suicidologi, 14 (1), 25-27.

Sosial- og helsedirektoratet. (2008). Nasjonale retningslinjer for forebygging av selvmord i psykisk helsevern. Rapport IS-1511. Oslo: Helsedirektoratet.

\section{Lovreferanser}

Helsepersonelloven (1999). Lov om helsepersonell m.v. LOV-1999-07-02-64

Pasientrettighetsloven (1999). Lov om pasientrettigheter. LOV-1999-07-02-63

Pasientskadeloven (2001). Lov om erstatning ved pasientskader m.v. LOV-2001-06-15-53

Nettadresser til aktuelle organisasjoner

Helsetilsynet: www.helsetilsynet.no

Pasientombudet: www.pasientombudet.no

Landsf. for pårørende i psykiatrien: www.lpp.no

Fri rettshjelp: www.fri-rettshjelp.no

Norsk pasientskadeerstatning: www.npe.no

Norsk pasientforening: www.pasient.no

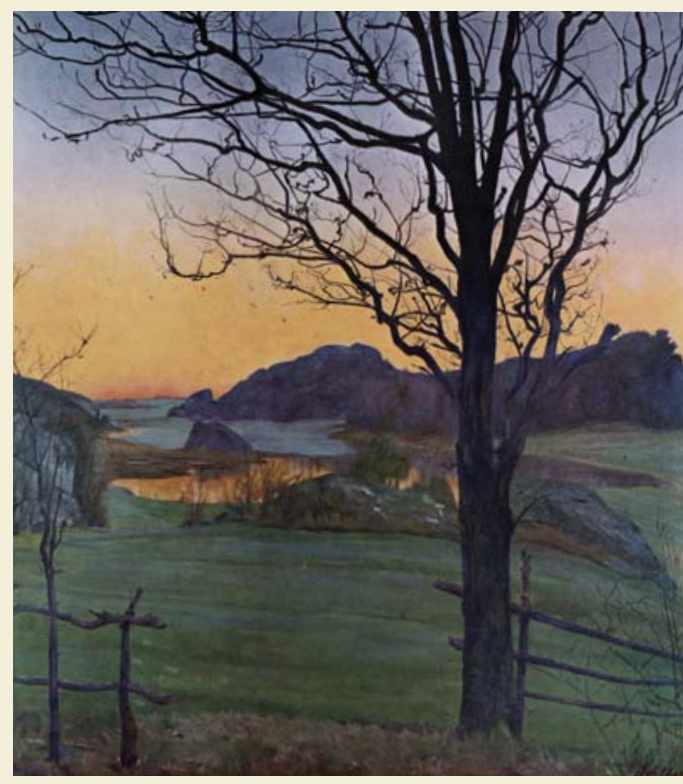

"Høstlandskap" (1910). Maleri av Harald Sohlberg (1869-1935)

\section{Borte!}

De sidste gæster

vi fulgte til grinden; farvellets rester tog nattevinden.

I tifold øde Iå haven og huset, hvor toner søde mig nys berused.
Det var en fest kun, før natten den sorte; hun var en gæst kun, og nu er hun borte.

Henrik Ibsen

Fra Digte (1871) 